\title{
Christian Thomasius, Invisible Philosophers, and Education for Enlightenment
}

\section{Eskildsen, Kasper Risbjerg}

Published in:

Intellectual History Review

DOI:

10.1080/17496970802319201

Publication date:

2008

Document Version

Publisher's PDF, also known as Version of record

Citation for published version (APA):

Eskildsen, K. R. (2008). Christian Thomasius, Invisible Philosophers, and Education for Enlightenment. Intellectual History Review, 18(3), 319-336. https://doi.org/10.1080/17496970802319201

\section{General rights}

Copyright and moral rights for the publications made accessible in the public portal are retained by the authors and/or other copyright owners and it is a condition of accessing publications that users recognise and abide by the legal requirements associated with these rights.

- Users may download and print one copy of any publication from the public portal for the purpose of private study or research.

- You may not further distribute the material or use it for any profit-making activity or commercial gain.

- You may freely distribute the URL identifying the publication in the public portal.

\section{Take down policy}

If you believe that this document breaches copyright please contact rucforsk@kb.dk providing details, and we will remove access to the work immediately and investigate your claim. 


\title{
CHRISTIAN THOMASIUS, INVISIBLE PHILOSOPHERS, AND EDUCATION FOR ENLIGHTENMENT
}

\author{
Kasper Risbjerg Eskildsen
}

\section{INTRODUCTION}

One of the eighteenth century's most ambitious attempts at defining the philosopher was Christoph August Heumann's journal, Acta philosophorum, published in Halle between 1715 and 1723. ${ }^{1}$ It was the world's first journal for the history of philosophy and a recurrent question was whether one could find a definition of the philosopher that applied throughout history and across the world. But the frontispiece of the first issue of the Acta philosophorum (Fig. 1) already revealed Heumann's own understanding of the role and place of the philosopher.

The upper half of the engraving depicts philosophy and theology as ascending 'in concord'. This peaceful conversation between reason and revelation reflected Heumann's concept of the Republic of Letters. $^{2}$ During the 1680s, Samuel Pufendorf and Christian Thomasius developed a parallel defence of freedom of belief and freedom of speech. ${ }^{3}$ Thomasius used this defence to redefine the Republic of Letters. ${ }^{4}$ Heumann was a sworn follower of Thomasius and considered him the Luther of philosophy. ${ }^{5}$ In 1718, he popularized Thomasius's new conception of the Republic of Letters in his Conspectus reipublicae litterariae, which, for most of the eighteenth century, served as the standard textbook for the history of learning at German universities. ${ }^{6}$ In the 1726 edition of the book, Heumann even added a footnote claiming:

\footnotetext{
${ }^{1}$ C. A. Heumann, Acta Philosophorum, das ist: Gründl. Nachrichten Aus der Historia Philosophica, Nebst beygefügten Urtheilen von denen dahin gehörigen alten und neuen Büchern, 18 vols (Halle, 1715-23). Also L. Braun, Histoire de l'histoire de la philosophie (Paris: Ophrys, 1973), 100-7.

${ }^{2}$ Also W. Sparn, 'Philosophische Historie und dogmatische Heterodoxie. Der Fall des Exegeten Christoph August Heumann', in Historische Kritik und biblischer Kanon der deutschen Aufklärung, edited by H. G. Reventlow, W. Sparn and J. Woodbridge (Wiesbaden: Harrassowitz, 1988), 171-92.

${ }^{3}$ S. Pufendorf, De habitu religionis christianae ad vitam civilem (Bremen, 1687), especially 46-7, and C. Thomasius, Freimütige, Lustige und Ernsthaffte iedoch Vernunfft- und Gesetz-Mässige Gedanken Oder Monats-Gespräche / über allerhand / fürnehmlich aber Neue Bücher, 5 vols (Halle, 1688-90), IV: 1148-9.

${ }^{4} \mathrm{~K}$. R. Eskildsen, 'How Germany Left the Republic of Letters', Journal of the History of Ideas, 65:3 (2004), 421-32.

${ }^{5}$ Heumann, Acta philosophorum, 1715-23, vol. 4, 609. Also G. Mühlpfordt, 'Ein kryptoradikaler Thomasianer: C. A. Heumann, der Thomasius von Göttingen', Christian Thomasius 1655-1728: Interpretation zu Werk und Wirkung, edited by W. Schneiders (Hamburg: Meiner, 1989), 305-34.

${ }^{6}$ C. A. Heumann, Conspectus reipublicae litterariae sive via ad historiam litterariam iuventuti studiosae (Hanover, 1718). There were at least eight further editions up until 1797.
}

Intellectual History Review

ISSN 1749-6977 print/ISSN 1749-6985 online

(C)2008 International Society for Intellectual History

http://www.informaworld.com/journals ～DOI: 10.1080/17496970802319201 


\section{CONCORDJA CRISCJMUS.}
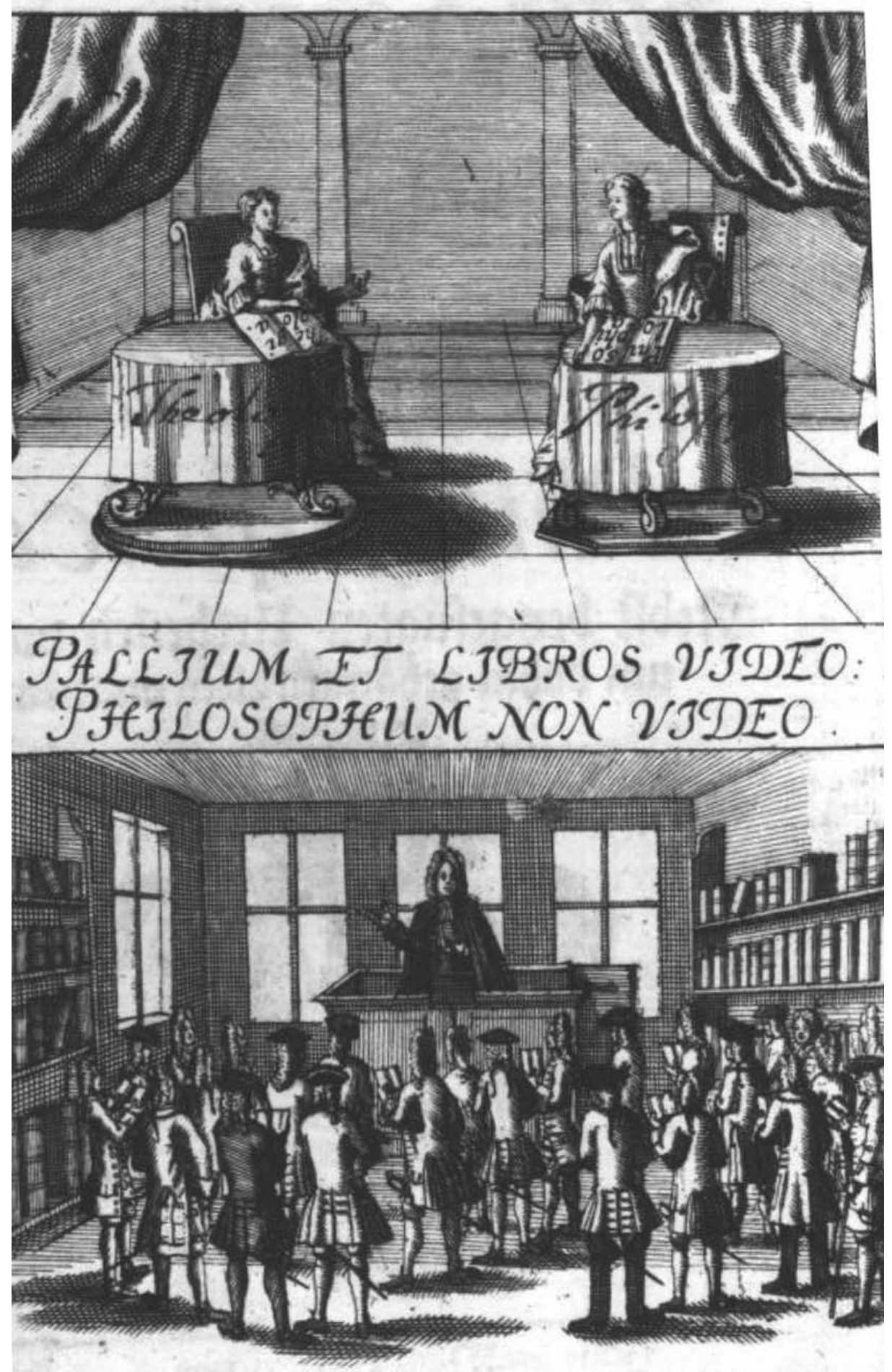

Fig. I Frontispiece in Christoph August Heumann, Acta Philosophorum, I 8 vols (Halle, 17I5-23), I 
The Republic of Letters is, in relation to its form, similar to the invisible church. There, only Holy Scripture rules and there is no monarch, no civil authority, but the highest freedom. Here, only reason rules, and no person has jurisdiction over another. And, this freedom is the soul of the Republic of Letters. ${ }^{7}$

The lower part of Heumann's frontispiece shows a professor and a group of students in a lecture hall. Heumann did not add the scene as a critique of contemporary education. If this had been his intention, he would have depicted both students and professor differently. For example, the frontispiece of Heumann's Der Politische Philosophus portrays various kinds of indecorous philosophers (Fig. 2): the Francophile fashion victim, the Catholic monk, the baroque scholar with his beard, and the antique Diogenes in his barrel. Above these false philosophers, the text declares: 'wisdom seldom hides under a dirty robe'.

In comparison, the students and professor in the lower section of the Acta philosophorum frontispiece are polished, modest and modern. The students are dressed in decent, but fashionable, clothing, wear short wigs and carry rapiers. The professor, as was customary at Thomasius's University of Halle, is wearing a black robe and a respectable full-bottomed wig, but not the traditional professorial hat, fur or beard. The lecture hall is very small and the walls are covered with books. Most likely, such a lecture hall would not have been public, but placed inside the professorial home - the preferred site for education in Halle. The students are all standing, indicating an egalitarian teaching environment.
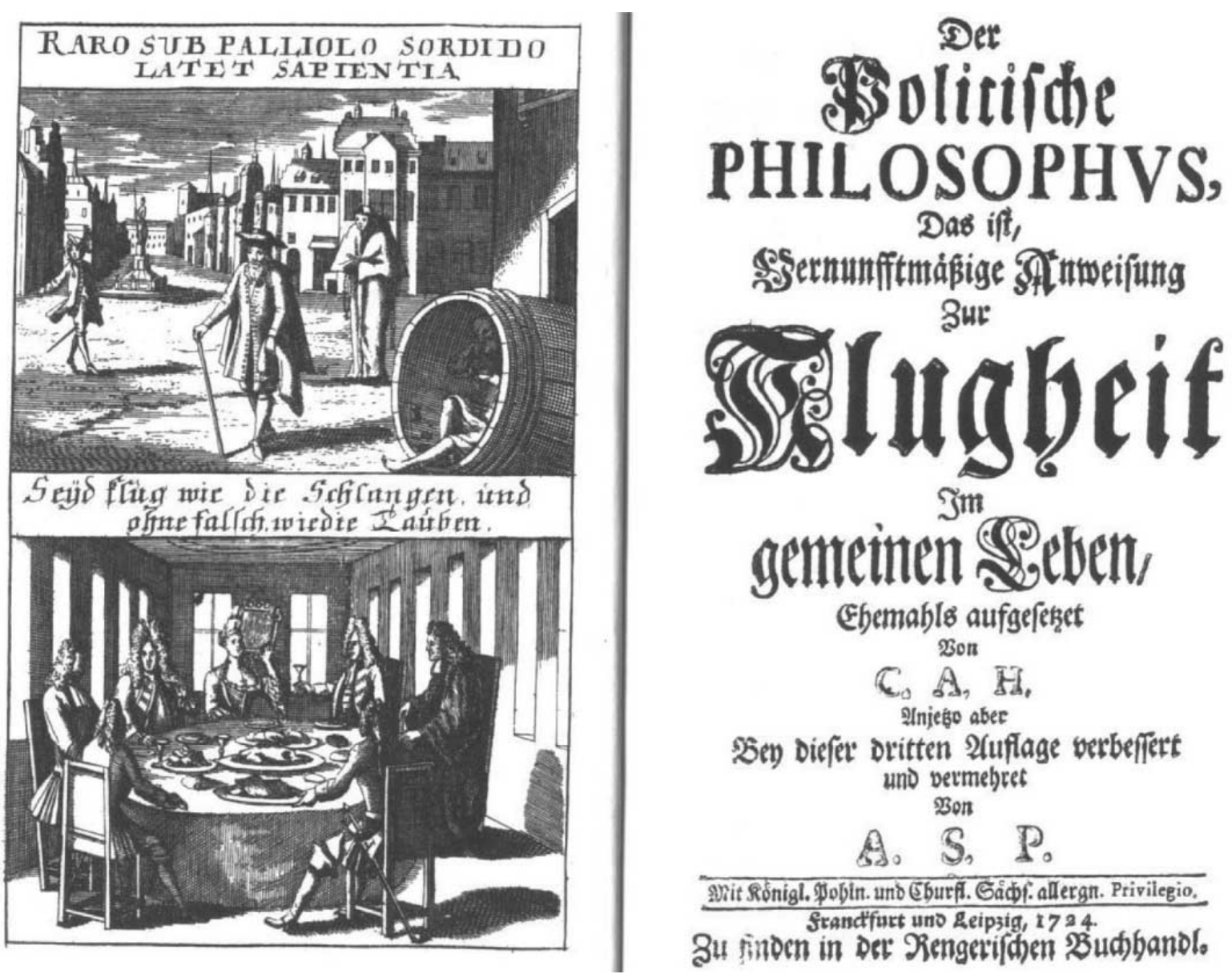

Fig. 2 Frontispiece in Christoph August Heumann, Der Politische Philosophus (Frankfurt am Main, 1724)

\footnotetext{
${ }^{7}$ Heumann, 1726, 198, note x: 'Resp. literaria ratione formae simillima est Ecclesiae invisibili. Vti hic nullus monarcha, nullum ciuile imperium, sed summa libertas, sola regnante S. Scriptura: sic illic sola regnat Ratio, nec quisquam in alterum quisquam habet iuris ciuilis. Ac libertas ista adeo est reip. literariae anima.'
} 
For a philosopher of the Thomasius school, such as Heumann, the scene would have been close to ideal. Nevertheless, the text over the picture states: 'I see the robe and the books; I do not see the philosopher'.

Placed in front of the Acta philosophorum, the engraving undoubtedly showed a professor of philosophy teaching students how to become philosophers. Thomasius and his most prominent followers were university professors, and, in his editorial preface, Heumann described the Acta philosophorum as an educational project. ${ }^{8}$ The history of philosophy should not only inform and entertain, but also improve its readers. Through his journal, Heumann insisted, they would become more intelligent and tolerant, and those who 'made scholarship their profession', 9 would benefit especially. Heumann's choice of frontispiece only further emphasized this educational purpose.

Philosophers, the frontispiece implied, could be found in lecture halls, even if they could not be seen there. They were present but invisible - hiding in an equally invisible Republic of Letters. The realm of the philosopher was not the realm of visual appearances, as the indecorous philosophers' distinctive dress and manners erroneously implied, and not even the still tangible realm of written words and printed books. The philosopher was only manifest as philosopher through his disembodied arguments, circulating freely within the private lecture hall.

\section{THOMASIUS'S THEORY OF FUNCTIONALIST PERSONAE}

Thomasius delivered his textbook definition of the philosopher in his Einleitung zur Vernunfft-Lehre of 1691. However, already during the 1680s, Thomasius developed a theory about the various personae of scholars. This theory was an adaptation of Samuel Pufendorf's functionalist theory of social personae, recently discussed by Theo Kobush. ${ }^{10}$ Thomasius applied the theory to scholars in particular, and thereby challenged and redefined such existing scholarly concepts as academic freedom, the Republic of Letters, and the philosopher as a distinctive kind of intellectual persona.

Thomasius launched his theory of scholarly personae within the context of his conflict with the Danish court chaplain Hector Gotfred Masius. The conflict with Masius centred upon the relationship between absolutism and Christianity. ${ }^{11}$ However, for Thomasius, this discussion was intimately connected to the parallel discussion about the relationship between absolutism and scholarship. Masius and Thomasius in many ways resembled one another. They were both progenies of academic families and belonged to the same generation - Masius was born in 1653, Thomasius in 1655. They were both impressed with Louis XIV's France and advocated French taste and social ideals. Masius had travelled all over Northern Europe and lived for years in Paris. After he returned to Copenhagen in 1686, he caused a commotion with his French style of preaching and by wearing a large full-bottomed wig at the pulpit. Thomasius did not travel as much, but acquired his Francophile taste at home in Leipzig. Nevertheless, in 1687, he enraged his colleagues and townsmen with his lectures on 'How to Imitate the French'. ${ }^{12}$ Thomasius and Masius also agreed that philosophy should serve the new order of absolutism, although they disagreed over how. Masius advocated the theory of theocratic absolutism, embodied in the just Lutheran ruler Christian V of Denmark. Thomasius ridiculed Masius's position

\footnotetext{
${ }^{8}$ On the Thomasius school, see M. Wundt, Die deutsche Schulphilosophie im Zeitalter der Aufklärung (Tübingen: Mohr, 1945), 19-121, and H. Rüping, Die Naturrechtslehre des Christian Thomasius und ihre Fortbildung in der Thomasius-Schule (Bonn: Röhrscheid, 1968).

${ }^{9}$ Heumann, Acta philosophorum, 1715-23, vol. 1, 4: 'von der Gelehrsamkeit profession machen'.

${ }^{10} \mathrm{~T}$. Kobusch, 'Pufendorfs Lehre vom moralischen Sein', in Samuel Pufendorf und die europäische Frühaufklärung, edited by F. Palladini and G. Hartung (Berlin: Akademie Verlag, 1996), 63-73.

${ }^{11}$ F. Grunert, 'Zur Aufgeklärten Kritik am theokratischen Absolutismus. Der Streit zwischen Hector Gottfried Masius und Christian Thomasius über Ursprung und Begründung der summa potestas', in Christian Thomasius (1655-1728). Neue Forschungen im Kontext der Frühaufklärung, edited by F. Vollhardt (Tübingen: Niemeyer, 1997), 51-78.

${ }^{12}$ C. Thomasius, Christian Thomas eröffnet der Studirenden Jugend zu Leipzig in einem Discours Welcher Gestalt man denen Frantzosen in gemeinen Leben und Wandel nachahmen solle? (n.p., n.d.). Also H.-J. Engfer, 'Christian Thomasius: Erste Proklamation und erste Krise der Aufklärung in Deutschland', in Christian Thomasius (1655-1728): Interpretation zu Werk und Wirkung, edited by W. Schneiders (Hamburg: Felix Meiner, 1989), 21-36.
} 
(to the great irritation of the court in Copenhagen), and, following Pufendorf, advanced a conception of politics that was 'secular' in the sense that the exercise of sovereignty is restricted to the goal of maintaining social peace.

Thomasius's conflict with Masius had serious consequences for the young philosopher. After years of controversy - including an additional debate about cross-confessional marriages - the Saxon court in March 1690 ordered Thomasius not to publish, lecture nor dispute any further. Thomasius was forced into exile in Brandenburg-Prussia and remained there for the rest of his life, as professor at the new University of Halle. However, before leaving Saxony, he defended his position in his short-lived literary journal, the Monatsgespräche. Thomasius denied that he could be blamed for offending the Danish court. His opponents only persecuted him, he explained, because they did not understand that scholars had multiple personae or 'characters'. For some of these personae, obedience and politeness were essential. However, while writing, one was no longer bound by these obligations:

[T]he moment he enters a trade, which is common to all human beings, he also simultaneously puts aside his political character, which he otherwise bears, and simultaneously silently frees all other scholars from the respect that they otherwise, in considering his political character, have the duty to show him. ${ }^{13}$

Thomasius's theory of functionalist personae blurred the borders between the Republic of Letters and the surrounding civil world. According to the theory, the scholars did not become scholars because of their education, institutions, traditions, habits or privileges. Being a scholar was not a privileged way of life, but a function within a broader civil order - that is, the function of producing reasoned arguments in writing. When scholars were not writing, they were just citizens and bound by the same rules and conventions as all other citizens. Thomasius's endorsement of fashionable French clothing signified his acceptance of these conventions. So too did his insertion of decorum - as a discipline for governing conduct - into the standard curriculum in practical philosophy, next to moral philosophy and natural law. ${ }^{14}$ University professors also had no monopoly on being scholars. Anyone producing reasoned arguments in writings was, by definition, a scholar. This was even the case if the one publishing was someone with political power. When one entered into learned discourse, one stopped being political, as one "leaves this character behind and through the editing of a book mingles with scholars of much lower rank (according to reason of state).${ }^{15}$ In writing, political distinctions were irrelevant, even if one were debating with a prince.

Thomasius's theory of functionalist personae, and his defence of the freedom of scholarly speech, depended upon his individualized eclecticism. ${ }^{16}$ In his Introductio in philosophiam aulicam of 1688 , Thomasius presented this programme for eclectic philosophy. He criticized sectarian school philosophers and argued that true philosophizing demanded the ability and will of the individual freely to select between arguments. The free persona of the scholar guaranteed that as many arguments as possible were available. In 1715, this eclectic programme also served as justification for Christoph August Heumann's Acta philosophorum. The eclectic philosopher not only needed access to the arguments of his contemporaries, but also to the arguments of past philosophers. ${ }^{17}$ In his editorial preface, Heumann

\footnotetext{
${ }^{13}$ Thomasius, Monatsgespräche, 1688-90, vol. 4, 1150: 'Denn idem er sich in ein Hand-werck mischt / daß allen Menschen gemein ist so leget er gleichsam den Politischen character, so er sonst trägt / ab/und erläst gleichsam stilleschweigend allen andern Gelehrten die Hochachtung / die sie ihm sonst in Ansehung desselben zu erweisen schuldig waren.'

${ }^{14}$ K. R. Eskildsen, 'Print, Fashion, and the Making of the Enlightenment Philosopher', in Northern Antiquities and National Identities: Perceptions of Denmark and the North in the Eighteenth Century, edited by K. Haakonssen and H. Horstbøl (Copenhagen: The Royal Danish Academy of Science and Letters, 2008), 126-44.

${ }^{15}$ Thomasius, Monatsgespräche, 1688-90, vol. 4, 1151: 'diesen character verläst / und sich durch edirung eines Buchs unter die (nach der Staats raison zu rechnen) viel niedringen Gelehrten mischet'.

${ }^{16}$ H. Dreitzel, 'Zur Entwicklung und Eigenart der "eklektischen Philosophie”, ,Zeitschrift für historische Forschung, 18:3 (1991), 281-343, especially 324-30. Also M. Albrect, ‘Thomasius - kein Eklektiker?', in Christian Thomasius (1655-1728). Interpretation zu Werk und Wirkung, 73-94, and Eklektik: eine Begriffsgeschichte mit Hinweisen auf die Philosophie- und Wissenschaftsgeschichte (Stuttgart: Frommann-Holzboog, 1994), 398-416.

${ }^{17}$ Also U. J. Schneider, 'Eclecticism and the History of Philosophy', and M. Mulsow, 'Gundling versus Buddeus: Competing Models of the History of Philosophy', in History and the Disciplines. The Reclassification of Knowledge in Early Modern Europe, edited by D. R. Kelley (Rochester: University of Rochester Press, 1997), 83-101 and 103-26.
} 
even claimed 'that no one deserves the name philosopher, who is not an eclectic' ${ }^{18}$ The history of philosophy should accustom his readers to 'endure the brightness of paradoxical truths'. ${ }^{19}$

\section{THOMASIUS'S EDUCATIONAL PROGRAMME IN HALLE}

Thomasius's first larger publication, after his arrival in Halle, was his Einleitung zur Vernunfft-Lehre of 1691. The book not only introduced readers to the 'art of reasoning', as promised in the title, but also outlined Thomasius's educational programme. In his dedication, Thomasius applied his theory of personae to the mayor of Leipzig, Adrian Stegern. Although Stegern in his daily life was occupied with public duties and worldly affairs, he also embodied various scholarly personae. As a theologian, Stegern was without prejudice. As a lawyer, he was a man of practice and familiar with natural law. However, above all, Thomasius celebrated the mayor as a model philosopher:

A righteous philosopher [Weltweiser] I understand to be a man, who always reasons fairly and concisely with a sharp and penetrating reason; who is well-familiar with the common and most useful instrument of all studies $[\ldots]$ history; who begins his philosophy with self-reflection and, through the suppression of his passions, seeks [...] the inner peace of the soul; who next to this knows the wickedness of the world, and [...] in conversations with people penetrates into their inner thoughts [...] who is able to find a suitable profession according to his ability and birth [...] Yes, finally one who acts [...] according to decorum, without which all philosophy would be vain and pure pedantry. ${ }^{20}$

Thomasius's classes in Halle were supposed to transform his students into 'civil' philosophers like the mayor of Leipzig. He wanted to educate practical men of the world, who, simultaneously, were prudent and penetrating philosophers. In some ways, Thomasius's pedagogical routines were traditional, following the conventions of European universities since the Middle Ages. He started with lectures and ended with exercises, testing the students' comprehension and correcting mistakes and misinterpretations. However, Thomasius differentiated this conventional scheme according to different degrees of privacy. The more private his classes were, the more he allowed for debate and critique. His students did not enter the free sphere of scholarship when they entered the university, but when they entered his house where he held his most private seminars.

After his public lectures, Thomasius gathered his students within his private collegium. On the surface, there was little difference between his public lectures and the first hour of his private collegium. Thomasius continued lecturing and some of these private lectures, for example on moral philosophy, were also free of charge. ${ }^{21}$ However, the private collegium in the following hour was more

\footnotetext{
${ }^{18}$ Heumann, Acta philosophorum, 1715-23, vol. 1, 20: ‘daß keiner den Nahmen eines Philosophi verdiene / der nicht ein Eclecticus ist.'

${ }^{19}$ Heumann, I: 26: 'den Glantz paradoxer Wahrheiten zu vertragen'.

${ }^{20} \mathrm{C}$. Thomasius, Einleitung zu der Vernunfft-Lehre, worinnen durch eine leichte / und allen vernünfftigen Menschen / waserley Standes oder Geschlechts sie seyn / verständliche Manier der Weg gezeiget wird / ohne die Syllogisticâ das wahre / wahrscheinliche und falsche von einander zu entscheiden / und neue Warheiten zu erfinden (Halle, 1691), unpag: 'Ich verstehe aber durch einen rechtschaffenen Weltweisen einen Mann / der einen Scharffsinnigen und penetranten Verstand hat / und allezeit just und bündig raisoniret: Der in dem allgemeinen und höchstnöthigen Instrument aller Wissenschaften / ich meine in der Historie, wohl erfahren ist; Der von seiner Selbsterkäntniß seine Philosophie anfängt / und durch die Dämpffung der Gemüths-Bewegungen sein höchstes Gut / die innerliche Gemüths-Ruhe sich zu verschaffen bemühet ist; Der nach diesem die Boßheit der Welt kennet / und durch eine tägliche / und auff unbetriegliche Regeln sich gründende Erfahrung allen Menschen mit denen Er conversiret / wenn sie auch noch so sehr dissimuliren / biß in das innerste ihrer Gedancken penetriret, und diese seine Wissenschafft zu Nutzen des gemeinen Besten / und zu Abwendung des gemeinen Schadens anzuwenden weiß: der geschickt ist / eine seinem Genio und Stande gemäße profession zu erkeisen / und die darzu gehörige / und / seine Tugend desto nachdrücklicher blicken zu lassen / nöthige Güter des Glücks rechtmäßig zu erwerben / die erworbenen zu erhalten / und zu vermehren und beyde nach der Richtschnur der gesunden Vernunfft unter die Bedürfftigen auszutheilen gelernet hat. Ja endlich der alles sein Thun und Lassen darnach einrichtet / daß man denenselben ein rechtmäßiges decorum / ohne welches alle Philosophie eitel und eine blosse Pedanterey seyn würde / handgreifflich spühren könne.'

${ }^{21} \mathrm{C}$. Thomasius, Allerhand bißher publicirte kleine Teutsche Schrifften / mit Fleiß colligiret und zusammen getragen; Nebst etlichen Beylagen und einer Vorrede (Halle, 1701), 650.
} 
exclusive and only for a small group of selected students, allowing for independent reflection. Here, Thomasius did not comment upon a book, but explained his own philosophy. In this so-called collegium privatissimum, he demanded active participation, taught his students to doubt, and engaged them in 'a continuous examination'.22 Those who attended all these classes, Thomasius promised, would within two or three years have finished their education. ${ }^{23}$

Thomasius's concerns about privacy reflected not only his conflict with Masius and the Saxon court, but also his experiences at the University of Leipzig. During the late 1680s, the Pietist August Hermann Francke caused a considerable commotion at the university with his biblical collegia. Francke, Thomasius later explained, provoked this commotion by removing his collegium from his house to a public lecture hall, where he attracted large crowds of students and, thereby, challenged the Leipzig theologians. ${ }^{24}$ Thomasius considered his own association with Francke as 'one of the major reasons why my [...] adversaries in Leipzig wanted to deprive me of life, honour, and property' ${ }^{25} \mathrm{He}$ even suspected that Francke's audacity had inspired his opponents to have 'spies at my lectures who wrote down what I said'. ${ }^{26}$

Most likely, Francke's biblical collegia were also an inspiration for the intensive exercises in Thomasius's collegium privatissimum. Francke instructed his students to disregard previous opinions and investigate Scripture for themselves. Such close readings not only served erudition, but also selfimprovement. Already in the foundational programme of the German Pietists, the Pia Desideria of 1675, Philipp Jakob Spener recommended such exercises for university students. 'Theology,' Spener claimed, 'is a habitus practicus and does not only consists of knowledge [Wissenschafft].' The students should therefore participate in 'all kinds of exercises [...] in which the mind is accustomed and trained in those matters that belong to praxis and the edification of oneself' ${ }^{27}$ Another possible Leipzig inspiration for Thomasius's collegium privatissimum was the early modern disputational collegia, where students took turns as opponents and respondents. These disputations, William Clark argues, were normally staged in the professorial home and only for paying students. The University of Leipzig also housed a number of private societies, such as the Collegium Gelanium and the Collegium Anthologicum, where students actively participated in the academic discussions. ${ }^{28}$

Thomasius combined the spiritual exercises of the Pietists with the collegia of early modern universities to create a new education for enlightened philosophers. Johann George von Raumer, who participated in Thomasius's collegium privatissimum from May 1692, described the experience. ${ }^{29}$ Raumer arrived in Halle well prepared. He was at the end of his studies and had already read Thomasius's books. However, immediately at their first meeting, Thomasius told him 'that all this is worth nothing and that if I believed him, I would forget everything I already knew' ${ }^{30}$ Thomasius explained that he needed a further two years of private education and that this would cost him 80 Thaler. Two years later, Thomasius ordered Raumer to leave Halle again, since he considered his education over.

\footnotetext{
${ }^{22}$ Thomasius, Vernunfft-Lehre, 1691, 21: 'ein continuirliches examen'.

${ }^{23}$ Thomasius planned such a short education for future courtiers while in Leipzig, but without distinguishing between public and private classes. See Thomasius, Kleine Teutsche Schrifften, 1701,233-70. However, already in Leipzig, one of the faculty's many complaints about Thomasius was his 'Aufrichtung eines auditorii domestici', C. Thomasius, Ernsthaffte, aber doch Muntere und Vernüfftige Thomasische Gedancken u. Erinnerungen über allerhand Juristische Händel, 4 vols (Halle, 1723-5), vol. 3, 16.

${ }^{24} \mathrm{C}$. Thomasius, Vernünfftige und Christliche aber nicht Scheinheilige Thomasischen Gedancken und Erinnerungen uber allerhand Gemischte Philosophische und Juristische Händel, 3 vols (Halle, 1723-5), vol. 2, 352-492.

${ }^{25}$ Thomasius, Vernünfftige, vol. 2, 353: 'eine mit von denen Haupt-Ursachen, die meine schon vielfältig erwehnte Adversarios zu Leipzig irritirte, mich um Lieb, Ehre und Gut zu Bringen'.

${ }^{26}$ Thomasius, Vernünfftige, vol. 2, 63: 'in meinen Lectionibus ihre Spionen hatten, und mir nachschreiben liessen'.

${ }^{27}$ P. J. Spener, Pia Desideria: Oder herzliches Verlangen nach Gottgefälliger Besserung der wahren Evangelischen Kirchen (Frankfurt am Main, 1680), 144: 'die Theologia ein habitus practicus ist / und nicht in blosser wissenschaft bestehet [...] So wäre dahin zu gedencken / wie allerhand übungen angestellet werden möchten / in denen auch das gemüht zu den jenigen dingen / die zu der praxi und eigenen erbauung gehören / gewehnet und darin geübet würde'.

${ }^{28}$ W. Clark, Academic Charisma and the Origins of the Research University (Chicago: University of Chicago Press, 2006), 143-58.

${ }^{29}$ Neues Allgemeines Archiv für Geschichtskunde des Preussichen Staates, edited by L. von Ledebur, 3 vols (Berlin, 1836), vol. 1, 187-95.

${ }^{30}$ von Ledebur, 188: 'daß das alles nicht werth sey und wenn ich ihm glauben wolle, wüsse ich selbst vergessen, was ich schon wisse'.
} 
While in Halle, Raumer dedicated most of his time and energy to his studies with Thomasius. Four hours each week he played ball games with his friends, two hours were occupied with dancing lessons, and one hour he relaxed with Italian language training. The rest of his time, he spent with Thomasius. The classes alone lasted four to five hours each day. In his free time, Raumer had to prepare for the intense exercises in the collegium privatissimum. For example, for rhetoric, each student had to 'choose a subject from antique or modern history and write apologies, either orations or letters, in German or Latin'. ${ }^{31}$ The students wrote these papers independently and received Thomasius's corrections and comments later. The exercises in moral philosophy were even more demanding:

$[\mathrm{H}] \mathrm{e}$ exercised us for a long time in the praxis or - as we called it - the art of knowing oneself and others well. Yes, he demanded from us in his [collegium] privatissimum that each [first] should describe his own temperament in writing and hand it over to him, and then [describe the temperament] of another participant [...] yes, even [the temperament] of Thomasius himself. In this way, we made one another blush and laugh. Later, he gave us assignments about such temperaments from holy and secular history; I, for example, had to work out the temperaments of King David and Emperor Charles V and explain my conclusions. ${ }^{32}$

Thomasius's distinction between public lectures and private collegia was more complicated than his previous distinction between writing and non-writing. When the students first entered the collegium privatissimum, they were not calm philosophers, but blushed and laughed when confronted with one another's weaknesses. Disinterestedness and detachment demanded habituation. Thomasius's innovative educational techniques served such habituation. For example, the use of writing, instead of the traditional oral tests, objectified the students' reactions on paper and created observational distance.

Thomasius claimed that his Einleitung zur Vernunfft-Lehre was written for 'all reasonable human beings', independent of social standing and gender. ${ }^{33}$ However, the young people who attended his collegia and used the textbook were not this egalitarian. Raumer remembered that August Hermann Francke, who was called to Halle in December 1691, had women in his audience, 'while Thomasius only taught men'. ${ }^{34} \mathrm{He}$ also recalled that 'a large number of young men of distinction had followed [Thomasius from Leipzig] or arrived later in Halle'. ${ }^{35}$ Thomasius himself bragged that his first Halle lectures attracted more than fifty auditors, many of whom were of high nobility. ${ }^{36}$

In his collegia, Thomasius suppressed these social differences. In Spener's model spiritual exercises, students should read the Bible in an atmosphere of 'confidentiality and friendship' and the professor should teach by example rather than by authority. ${ }^{37}$ Thomasius went even further. He calculated the tuition according to income and the poorest students participated free of charge. Raumer recalled that Thomasius immediately prohibited the students from calling him 'your Excellency', and that none of the students received special treatment because of their background. Thomasius, more than any other professor, Raumer explained, 'accustomed the youth to a lovable candour and unrestraint'.38 Thomasius often warned his students about what awaited them if they enrolled in his collegia, where he would disregard riches, rank and nobility. Inside the lecture hall, nothing but talent mattered and 'the nature and reason of distinguished and rich people are not different or better than that of inferiors

\footnotetext{
${ }^{31}$ von Ledebur, 190: 'einen gegenstand aus der alten oder neuen Historie erwählen und, in einer Rede oder Briefform, Apologien in teutscher oder Lateinischer Sprache machen müßte’.

${ }^{32}$ von Ledebur, 193-4: 'so übte er uns längere Zeit in der Praxis oder, wie wir es nannten, in der Kunst: sich selbst und andere Leute wohl zu kennen, ja er verpflichtete uns in seinem Privatissimum, daß jeder schriftlich sein eignes Temperamentum morale auffetze und ihm übergebe, dann das der anderen Theilnehmer [...] ja sogar des Thomasius selbst. So machte man sich wechselseitig erröten und lachen. Dann gab er uns Aufgaben solcher Temperamente aus der heiligen und Profangeschichte, z.B. mußte ich König Davids und Kaiser Carls des fünften Temperamente mit Entscheidungsgründen ausarbeiten’.

${ }^{33}$ Thomasius, Vernunfft-Lehre, 1691, frontpage: 'allen vernünfftigen Menschen / waserley Standes oder Geschlechts sie seyn'.

${ }^{34}$ von Ledebur, Neues Allgemeines Archiv, 1836, vol. 1, 191: 'während Thomasius nur Männer unterrichtete'.

${ }^{35}$ von Ledebur, 190: 'eine große Menge vornehmer junger Leute waren ihm gefolgt oder kamen noch nach Halle'.

${ }^{36}$ Thomasius, Philosophische und Juristische Händel, 1723-25, vol. 2, 118-19.

${ }^{37}$ Spener, Pia Desideria, 1680, 146: 'verträulichkeit und freundschaft'.

${ }^{38}$ Ledebur, Neues Allgemeines Archiv, 1836, vol. 1, 192: 'gewöhnte die Jugend an eine Liebenswürdige Freimüthigkeit und Zwangslosigkeit'.
} 
and subordinates' ${ }^{39}$ Thomasius's own professorial authority was also open for questioning. '[T]he more they doubt me, yes, the sharper they oppose me,' he claimed, 'the more pleased I will be. ${ }^{40}$

Even forewarned, students were sometimes surprised by the candid tone. Zacharias Conrad von Uffenbach, who from 1701 attended Thomasius's two-year programme for law students, remembered that his teacher 'used to flavour his lectures, almost to excess, with jokes and buffoonery, and, often violating decorum, also with scoffing judgements and anecdotes about his colleagues and other learned men'. ${ }^{41}$ Laughter and embarrassment not only distanced Thomasius's students from themselves, but also taught them to question learned authorities, including the professors at the University of Halle. Uffenbach bemoaned that his fellow students adopted Thomasius's style. During the discussions, they were transformed into 'rather tasteless followers and defenders of contradicting principles'. ${ }^{42}$ Uffenbach continued,

Yes, frankly speaking, almost all of Thomasius' auditors suffer from the weakness that they make a great effort to cultivate newer, odder, and more paradoxical opinions, and, therefore, normally appear difficult, suspect, and leprous to other people, especially those from the clerical estate. ${ }^{43}$

One of these clerics, the minister Martin Günter, who briefly visited Thomasius's collegium on canon law in 1721, also recalled the disrespectful manner. Thomasius, Günter complained, 'made it his main job to mock the theologians of Wittenberg and Leipzig through and through, and, at the same time, scandalously turning many wonderful common places upside down or even scornfully ridiculing previous interpretations'. ${ }^{44}$ Günter later disputed some of Thomasius's comments. The philosopher did not ignore the difficult visitor, but, on the contrary, 'kept me with him in his library for two and a half hours, even though I wanted to leave several times'. 45

When Thomasius and his students returned to the social world, however, their political personae replaced their scholarly personae. Outside the lecture hall, the rules of decorum, which Raumer, Uffenbach and Günter witnessed so violated, again applied. Thomasius explained to his students in 1693 ,

During the hour that my lecture lasts, I will forget your social standing and wealth, and only consider you as students, who need every good admonition and teaching. When I am not upon the lectern, then the distinction that one must make among you according to decorum again comes into effect. ${ }^{46}$

Outside the lecture hall, the students were also not allowed to continue the heated debates. 'Most of all,' Thomasius admonished, 'they shall take care not to dispute and quarrel with one another. When

\footnotetext{
${ }^{39} \mathrm{C}$. Thomasius, Summarischer Entwurf der Grundlehren, die einem Studio Juris zu wissen / und auff Universitäten zu lernen nöthig sind (Halle, 1699), 40: 'Daß vornehme und reiche Leute keine andere und bessere Natur noch Verstand haben / als niedrige und geringe.'

${ }^{40}$ Thomasius, Vorrede, unpag: 'Je mehr sie mich absonderlich besuchen und je mehr dubia sie mir machen, ja, je schärfer sie mir opponieren werden, je lieber wird es mir sein.'

${ }^{41}$ Z. C. von Uffenbach, Merkwürdige Reisen durch Niedersachsen Holland und Engelland, 3 vols (Frankfurt am Main, 1753-4), vol. 1, XLVIII: 'seine Lesestunden mit Scherzen und Possen fast zu Uebermas und nicht selten wider den Wolstand, auch mit spöttischen Urtheilen und Histörgen von seinen Herrn Collegen und andern gelehrten Männern zu würzen’.

${ }^{42}$ von Uffenbach, vol. 1, XLIX: 'zimlich abgeschmackte Anhänger und Vertheidiger widersinniger Sätze'.

${ }^{43}$ von Uffenbach, vol. 1, XLIX: 'Ja, wenn ich recht freymüthig von der Sache reden soll, so sind fast alle Thomasianischen Zuhörer an diesem Fehler krank, daß sie sich neuer, sonderbarer, und paradoxer Meynungen befliessigen, und daher andern Leuten, sonderlich denen vom geistlichen Stande beschwerlich, verdächtig und aussätzig zu seyn pflegen.'

${ }^{44} \mathrm{~T}$. Wotschke, 'Eine Kollektenreise von Leipzig nach Wolfenbüttel im Jahre 1721', Thüringisch-Sächsische Zeitschrift für Geschichte und Kunst, 16:1 (1927), 79-94, 85: 'Nebst dem Guten, das er vorbrachte, ließ er ein Hauptwerk sein, die Wittenberger und Leipziger Theologen, alte und neue, auf das spitzigste durchzuhecheln, ingleichen viele herrliche loca schändlich zu verkehren oder doch die bisherige Auslegung hönisch zu verlachen.'

${ }^{45}$ Wotschke, 85: 'behielt mich durch 2 1/2 Stunden, ungeacht ich etliche Male gehen wollte, bei sich auf der Bibliothek'.

${ }^{46}$ Thomasius, Kleine Teutsche Schrifften, 1701, 610-1: 'Solange als die Stunde meiner lectionum währen wird, werde ich eures Standes und Vermögen vergessen und euch bloß als Studenten betrachten, die ihr alle gute Vermahnung und Lehre vonnöten habet. Bin ich von dem Katheder herunter, so gehet hernach der Unterschied, den man propter decorum unter euch manchen muß, wieder an.'
} 
they are opposing or responding in the lecture halls, then they may dispute as well as they can. But in conversations or at the table this appears very scholastic and pedantic. ${ }^{.47}$

Only a few students at the time could participate in Thomasius's intensive two-year programme and, in the spring of 1701, he changed his teaching routines to accommodate the increasing number of students arriving in Halle. He abandoned the collegium privatissimum and only offered public lectures and private collegia. ${ }^{48}$ The private collegia would be much cheaper and open for all students, but Thomasius ensured that he would continue teaching 'per modum collegiorum privatorum' ${ }^{49} \mathrm{He}$ also still encouraged his students to raise their doubts and contradict him in class. ${ }^{50}$ These new quasi-public private collegia immediately tested the limits. Already in October 1701, Thomasius protested that notes of students were circulating around the city. 'I,' Thomasius declared, 'hereby publicly protest against these [notes]. I do not accept them, or acknowledge them as my own, unless they agree with my other published works. ${ }^{51}$ Thomasius was especially distressed that some students, who only sporadically visited his classes propagated ideas that: 'appear either ridiculous or absurd or even dangerous and Godless' ${ }^{52} \mathrm{He}$ therefore decided again to close his collegium to the public, allowing only students who signed up at the beginning of the semester. ${ }^{53}$

One student, Johann Gottfried Zeidlern, who in April 1701 published a collection of notes from Thomasius's collegia, commented upon his teacher's dislike of such collections. According to Zeidlern, Thomasius had allowed his publication without edits, but also warned against the dangers of misreadings and misunderstandings. He admonished that his lectures were 'oral', delivered to 'young people' and not intended for a larger audience. Much would be incomprehensible, since 'he in his discourse presents sometimes the persona of the opponents and sometimes [the persona] of the respondent, in the manner of a collegium or a dialogue, which his audience quite easily noticed through change of tone or voice'. This 'variation of voices' did not come across well in writing. ${ }^{54}$ In the lecture hall, one also encountered 'vulgar and free similitudes and expressions, many digressions, often repetitions, etc.' and even expressions that appeared 'all-too-free or otherwise offensive' ${ }^{55}$ Although such similitudes and expressions were allowed in an educational context, they were not always suitable for publication. Students should remember, Thomasius informed Zeidlern, 'that there are many things that can be thought and not suitably said; others that can be said respectably but not respectably written; others again that can be written respectably but not suitably published' ${ }^{56}$

\section{THE PLACE OF DISINTERESTEDNESS}

Thomasius's distinctions between public lectures, private collegium, and collegium privatissimum depended upon the places where he taught. Public lectures were traditionally delivered in the lecture halls of the university. The lecture halls of the University of Halle were placed in the Weigh House,

\footnotetext{
${ }^{47}$ Thomasius, Summarischer Entwurf, 1699, Vorrede, unpag.: 'Am allermeisten aber werden sie sich hüten daß sie nicht untereinander selbst disputiren und zancken / wenn sie in Auditoriiis zu opponiren und zu repondiren haben /da mögen disputiren so gut als sie können. Aber in der Conversation und über Tische kommt es sehr Schulfüchsisch und Pedantisch heraus.'

${ }^{48}$ C. Thomasius, Außerlesene und in Deutsch noch nie gedruckte Schrifften, 2 vols (Halle, 1705-14), vol. 2, 193-220.

${ }^{49}$ Thomasius, Außerlesene, vol. 2, 196.

${ }^{50}$ Thomasius, Außerlesene, vol. 2, 276.

${ }^{51}$ Thomasius, Außerlesene, vol. 2, 261: 'ich protestire hiermit öffentlich darwieder / daß ich mich zu denenselben nicht bekenne / noch für die Meinigen agnoscire / so ferne sie nicht mit meinen andern publicirten Schrifften überein kommen'.

${ }^{52}$ Thomasius, Außerlesene, vol. 2, 262: 'aus wiedrigen principiis hergeleitete conclusiones einen entweder lächerlich und absurd oder wohl gar gefährlich und gottloß vorkommen'.

${ }^{53}$ Thomasius, Außerlesene, vol. 2, 277.

${ }^{54} \mathrm{C}$. Thomasius, Dreyfache Rettung des Rechts Evangelischer Fürsten in Kirchen-Sachen, edited by J. G. Zeidlern (Frankfurt am Main, 1701), Vorrede, unpag: 'Er in discursu bald opponentis, bald respondentis personas per modum colloguii vel dialogi præsentiret, welches von den Zuhören durch Veränderung des thons oder der Stimme gar leichtlich hat angemerckt / aber im nachschreiben diese variatio vocis nicht so deutlich exprimiret werden können.'

${ }^{55}$ Thomasius, Dreyfache, Vorrede, unpag.: 'gemeine und freye Gleichnüße und Redensarten / vielfältige disgressiones, öfftere repetitiones, u.s.w. [...] allzufrey oder sonst anstößig'.

${ }_{56}^{5}$ Thomasius, Dreyfache, Vorrede, unpag.: 'daß etliche Dinge seyn / die sich dencken und nicht füglich reden / andere / die sich wohl reden / aber nicht wohl schreiben / wieder andere / die sich wohl schreiben aber nicht füglich drucken laßen'.
} 
next to City Hall, which, in the early 1690s, also accommodated wedding celebrations, large meetings, guest comedians and livestock exchanges (Fig. 4). Later the entire building was used for lectures, but the Weigh House still reflected the hierarchical structures of society and the university ${ }^{57}$ One engraving from the early eighteenth century depicted the large lecture hall in the Weigh House. Following the traditions of early modern universities, the lecture hall was divided into different spaces according to rank and position (Fig. 3) ${ }^{58}$ Portraits of patrons decorated the walls and dignitaries were seated upon elevated plateaus above mere students and commoners.

The Weigh House was also a very public place. In 1732, one adviser to the Prussian government emphasized the virtues of public lectures. 'When the professors diligently lecture in public and in the public lecture halls,' he claimed, 'it adds to the good esteem and good reputation [of the university] among outsiders. ${ }^{59}$ Here, the professors presented themselves to 'the whole world' for 'in public

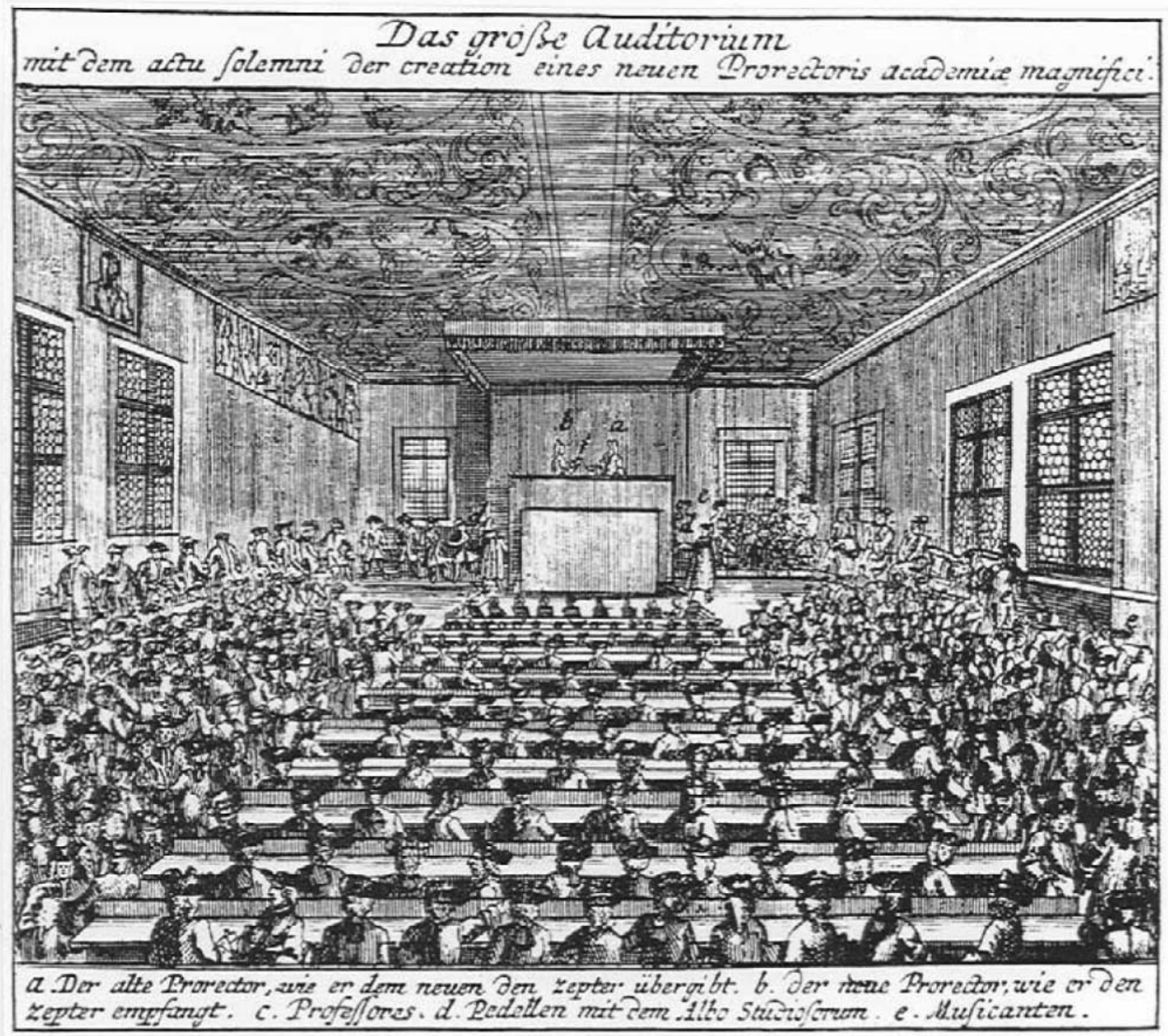

Fig. 3 Engraving of the large lecture hall in the Weigh House from the beginning of the eighteenth century

\footnotetext{
${ }^{57}$ J. C. von Dreyhaupt, Pagvs neletici et nvdzidi, oder ausführliche diplomatisch-historische Beschreibung des zum ehemaligen Primat und Ertz-Stifft, nunmehr aber durch den westphälischen Friedens-Schluss secularisirten Hertzogthum Magdeburg gehörigen Saal-Crë̈ses, und aller darinnen befindlichen Städte, Schlösser, Aemter, 2 vols (Halle, 1755), vol. 2, 5 and vol. 2, 36-7. ${ }_{58}$ Also Clark, Academic Charisma, 2006, 77-8.

${ }^{59}$ J. C. Hoffbauer, Geschichte der Universität zu Halle bis zum Jahre 1805 (Halle, 1805), 179, note c: 'Dient es zum guten Ansehen und guten Ruf bey Auswärtigen, wenn die Professores fleissig publice und in denen öffentlichen auditoriis ihre Collegia lessen.'
} 


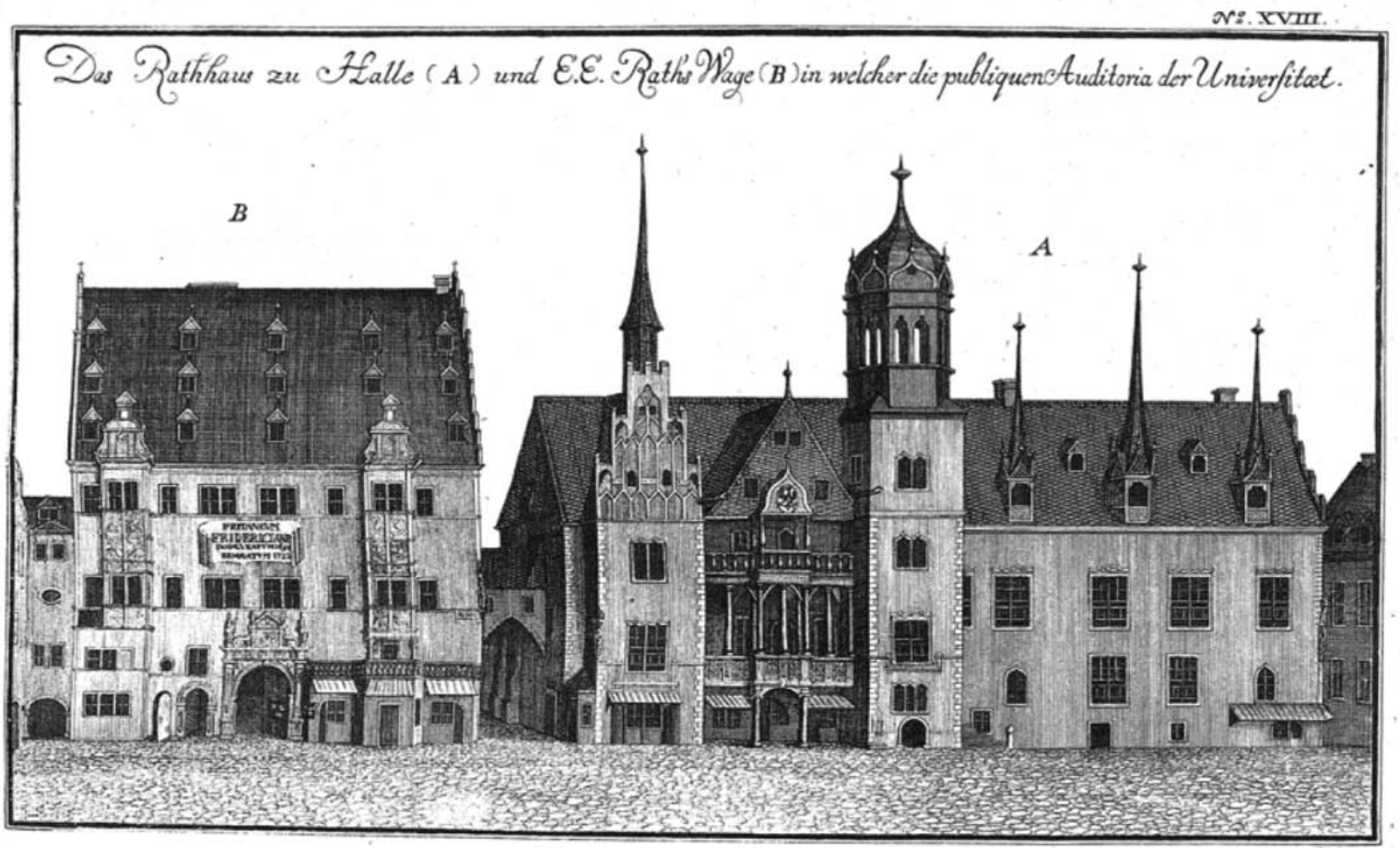

Fig. 4 Engraving of City Hall and the Weigh House from Johann Christoph von Dreyhaupt, Pagvs neletici et nvdzidi, 2 vols (Halle, I755), Il: tab. xviii

everyone who wants can listen' ${ }^{60}$ Since Thomasius lectured in German, he not only attracted students and local scholars, but also, as Johann Christoph von Dreyhaupt remarked, 'common citizens, who wondered about his new teachings' ${ }^{61}$ In such surroundings, Thomasius could not allow himself or his students to forget the rules of decorum.

Private collegia were traditionally taught in the professors' own houses. Early modern households did not offer the same privacy as modern homes. The house was still a centre of manufacture and social life. During the sixteenth and seventeenth centuries, however, the upper echelons of European society demarcated spaces, such as the bedroom, the closet and the cabinet, which allowed for various degrees of detachment from the surrounding world. ${ }^{62}$ Larger households were increasingly divided into spheres of intimacy and privacy. A similar development happened within professorial houses. Medieval scholars were, in principle, celibate and did not establish their own households. Early modern professors, on the contrary, surrounded themselves not only with wives and children, but also with servants, famuli and lodging students. ${ }^{63}$ Within these large households, however, professors established isolated spaces, such as libraries, studies and laboratories, for contemplation and scholarly work. Here, they not only avoided their extended families, but also distanced themselves from other temporal concerns. ${ }^{64}$ They even escaped the hierarchies of the traditional institutions of higher learning. One predicament of past scholarship, Thomas Sprat explained in his History of the Royal

\footnotetext{
${ }^{60}$ Hoffbauer, Geschichte, 180, note c: 'dass man sehen kann, wer etwas verstehet, und im Stande sey, so zu reden vor aller Welt aufzutreten und gute Lehren vorzutragen. Den in publicis kann zuhören, wer da will'.

${ }^{61}$ Dreyhaupt, Pagvs neletici et nvdzidi, 1755, II: 5: 'gemeinen Bürger-Leuten, die sich über seiner neuen Lehre verwunderten'. ${ }^{62}$ N. Elias, Die höfische Gesellschaft. Untersuchungen zur Soziologie des Königtums und der höfischen Aristokratie (Frankfurt am Main: Suhrkamp, 1997), 68-101. Also M. McKeon, The Secret History of Domesticity: Public, Private, and the Division of Knowledge (Baltimore: Johns Hopkins University Press, 2005).

${ }^{63}$ G. Algazi, 'Scholars in Households: Refiguring the Learned Habitus, 1480-1550', Science in Context, 16 (2003), 9-42.

${ }^{64} \mathrm{~S}$. Shapin, 'The House of Experiment in Seventeenth-century England', Isis, 79, 3 (1988), 373-404, and "“The mind is its own place”: Science and solitude in seventeenth-century England', Science in Context, 4 (1990), 191-218.
} 
Society of 1667, was that 'the Seats of Knowledge' had been universities and not private laboratories. At university, students were trained to submit to their professors and, Sprat claimed, 'the very inequality of the Titles of Teachers, and Scholars, does very much suppress, and tame mens Spirits'. Such settings were 'by no means consistent with free Philosophical Consultation'. ${ }^{65}$ In contrast, the direct observation of nature in laboratories 'gives us room to differ, without animosity, and permits us to raise contrary imaginations, ${ }^{66}$

Thomasius's withdrawal from the public lecture halls served a similar purpose. Inside his house, he and his students escaped hierarchies and indulged in paradoxes, disagreements and free scholarly discourse. Unlike the members of the Royal Society, they remained within the educational context of the university, but the walls of Thomasius's house protected them from many of the social and cultural demands of that institution. In the 1690s, when Thomasius and his students moved from his public lectures to lectures in his private collegium, they therefore walked from the Market Square down Galgstraße to his house by the Ulrichkirche (Fig. 5). ${ }^{67}$

Thomasius's decision in 1701 to abandon his collegium privatissimum and open his collegia for more students was only possible because of his changed living conditions ${ }^{68}$ In 1700 , Thomasius acquired and rebuilt a stately residence in Grosse Ulrichstraße. In the main building, facing the street, he furnished several rooms as private lecture halls. One of these halls was large enough to hold 150 students. ${ }^{69}$ Thus, Thomasius could teach a large audience 'per modum collegiorum privatorum'.

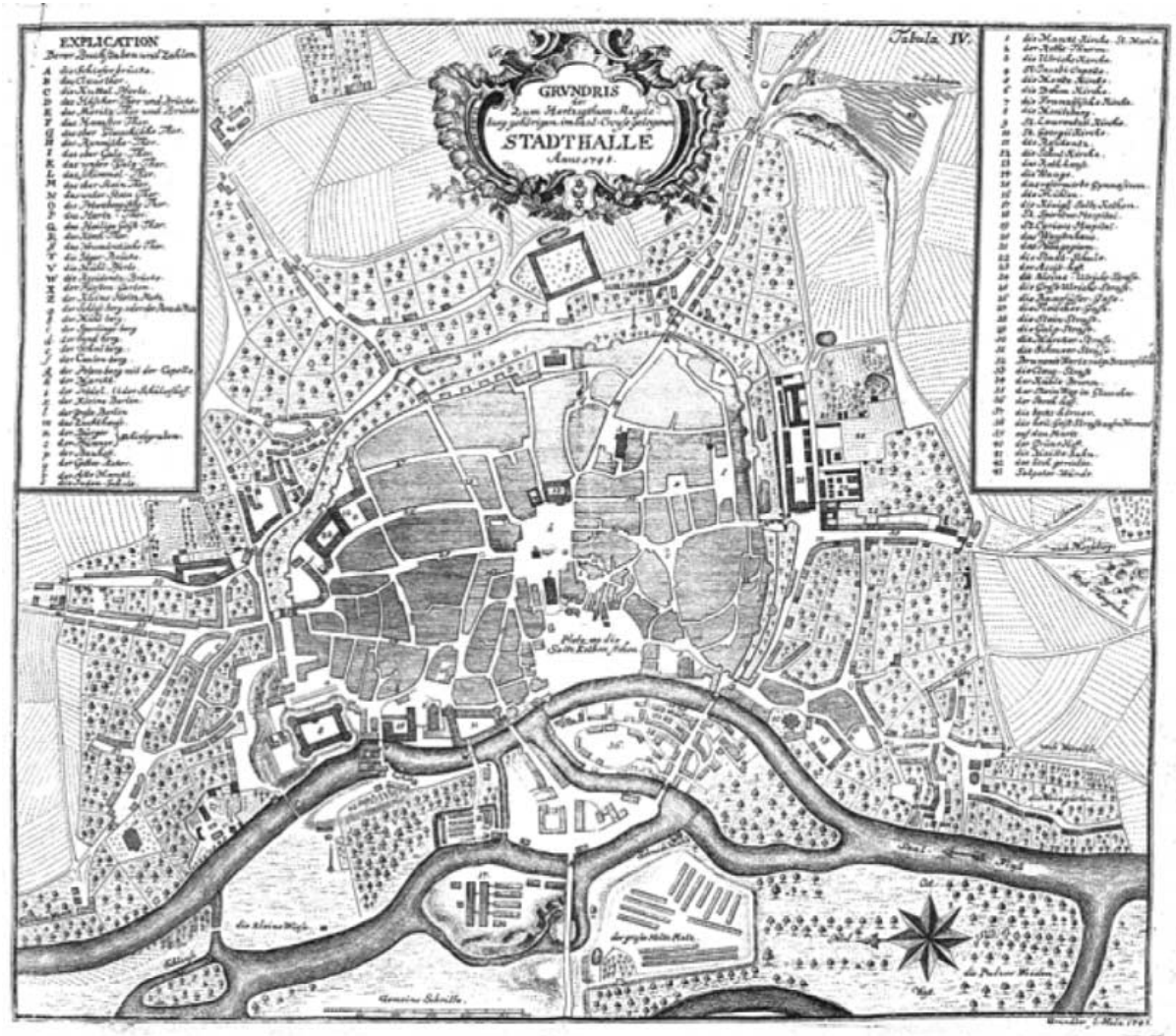

Fig. 5 Map of Halle in 1748 from Johann Christoph von Dreyhaupt, Pagvs neletici et nvdzidi, 2 vols (Halle, 1755), I: tab. iv

${ }^{65} \mathrm{~T}$. Sprat, The History of the Royal-Society of London for the Improving of Natural Knowledge (London, 1667), 68.

${ }^{66}$ Sprat, 56.

${ }^{67}$ Thomasius, Kleine Teutsche Schrifften, 1701, 634-5.

${ }^{68}$ Thomasius, Außerlesene Schrifften, 1705-14, vol. 2, 195. Also Erich Neuß, 'Christian Thomasius' Beziehungen zur Stadt Halle', Christian Thomasius: Leben und Lebenswerk, edited by Max Fleischmann (Halle, 1931), 453-78, esp. 463-74.

${ }^{69}$ Thomasius, Außerlesene Schrifften, 1705-1714, vol. 2, 209. 
Simultaneously, Thomasius started delivering public lectures within his private residence, escaping not only the conventions, but also the freezing unheated rooms of Weigh House. ${ }^{70}$

\section{THE THOMASIUS SCHOOL}

After Thomasius's death in 1728, the Halle professors maintained his educational programme, including his two-year programme for law students. In 1737, the university chancellor and Thomasius's successor in the faculty of law, Johann Peter von Ludewig, celebrated the virtues of this short programme. ${ }^{71} \mathrm{He}$ rejoiced that the intensive daily sessions in the private collegia connected students, erased social differences and motivated everyone to work. However, the chancellor disliked some of Thomasius's teaching techniques. In 1730, he even encouraged the government to dismiss professors who abused their freedoms, since:

The professors' revilement and abuse of their colleagues, above all within their collegia, do great damage to this university [...] this vice especially causes rifts at this [university] and, through it, the abusers gather followers and strive to further all kinds of harmful factions and errors [...] The university statutes do forbid this $[\ldots]$ but nonetheless they act against [these statutes] everyday. ${ }^{72}$

Not many of Ludewig's colleagues shared this opinion. In 1739, for example, the law professor Justus Henning Böhmer explained that 'The freedom of teaching [...] gave great momentum to the success of the university [of Halle] [...] Constraining the collegia is the mother of all evils' ${ }^{73}$ The Halle professors, including Ludewig, also preferred to teach their students at home. They equipped their residences with lecture halls and these halls accommodated not only private collegia, but also most of the university's public lectures. ${ }^{74}$ The professors protested loudly when, in 1735, the Prussian authorities ordered four new public lecture halls to be constructed in the former residence of Herzog August. The halls were constructed anyway, but, despite threats of military intervention, the plan proved futile. In 1755, Dreyhaupt reported, most of the rooms were used for housing and the rest, including the large hall facing the river, stood empty. ${ }^{75}$ The professors still delivered their 'public collegia in their private lecture halls'. ${ }^{76}$

Thomasius's teaching methods were also introduced at other universities. In 1693, Johann Franz Buddeus took over Thomasius's private collegium for philosophy students in Halle. In 1705, Buddeus was called as professor of theology to the University of Jena, where he offered theological exercises in the intimate and critical spirit of Thomasius's collegia. Buddeus gathered a 'closed assembly' of students in his house in his collegium privatissimum, where they presented 'their questions and doubts', both orally and on paper, and received their teacher's answers. ${ }^{77}$ These questions and answers often concerned personal matters, such as the students' relationship with their families,

\footnotetext{
${ }^{70}$ Thomasius, Außerlesene Schrifften, vol. 2, 209.

${ }^{71}$ J. P. von Ludewig, Gelehrte Anzeigen in alle Wissenschaften, so wol geistlicher als weltlicher, alter und neuer Sachen, 3 vols (Halle, 1749), vol. 2, 734-55.

${ }^{72}$ Die Gründung der Universität Göttingen: Entwürfe, Berichte und Briefe der Zeitgenossen, edited by E. F. Rössler (Göttingen, 1855), 446: 'Daß die schmähungen und lästerungen der professors, absonderlich in collegiis, gegen ihre collegen hiesziger Universität groszen schaden thun [...] Und weil dieses laster absonderlich an hieszigem ort einreiszet und die lästerer dardurch sich einen anhang zu machen und allerhand schädliche factiones und irrungen anzurichten suchen: so würde freylich sehr wohl gethan seyn, wann man diesem unheil gänzlich abgeholffen werden könnte. Die Statua academica verbiethen solches zwar [...] allein gleichwohl wird dawider täglich gehandelt.'

${ }^{73}$ Rössler, 455 'Die Freyheit zu lehren [...] hat ein groszes momentum zur Aufnahme der Universität gegeben [...] Die Einschrenkung derer Collegiorum is eine Mutter alles Uebels.'

${ }^{74}$ W. Schrader, Geschichte der Friedrichs-Universität zu Halle, 2 vols (Berlin, 1894), vol. 1, 331-7.

${ }^{75}$ Dreyhaupt, Pagvs neletici et nvdzidi, 1755, vol. 2, 541.

${ }^{76}$ Dreyhaupt, vol. 2, 38: 'Collegia publica in ihren privat-Aditoriis.'

${ }^{77} \mathrm{~J}$. F. Buddeus, Zu Jena kurtz vor seinem Tode gehaltenes Collegium oder colloquium privatissimum über neun und neunzig demselben von einigen seiner vertrautesten und gelehrtesten Zuhöhrern vorgelegte insoderheit aber einige Zinzendorfische Sätze und Anstalten betreffende Fragen, wie solche auf das getreulichste von einem Zuhörer desselben aus seinem Munde nachgeschrieben worden (Jena, 1744), 6: 'Fragen und Zweifel [...] geschlossenen Versammlung.'
} 
how one dealt with sinful fellow students, if fear of death was a sin, and if wigs were amoral. One daring student even left anonymous notes upon the lectern questioning fundamental Protestant dogmas. Buddeus did not publish his answers and, usually, the students did not take notes during these sessions. Only after Buddeus's death in 1729, were some of the written questions and answers discovered on his desk.

Most members of the Thomasius school realized that they did not enjoy the same freedom in writing as in their collegia. The distinction between inside and outside of the professorial residence had replaced Thomasius's old distinction between writing and non-writing. Only within the residence could one change personae. In 1727, Gottlieb Stolle advised his students in Jena that they could not understand what happened in contemporary scholarship from books alone. A student must, Stolle admonished, 'not just read, but also frequent the collegia of learned men and seek their company'.78 The closer the student came to the professor, the closer he came to the truth. 'One,' Stolle explained, 'does not write everything one knows. A teacher says much in his collegium, which he does not publish. In conversations, where only one or two are present, he is normally even more open-hearted than in the collegium, where the multitude in the lecture hall still holds him somewhat back. ${ }^{79}$

An interesting example is the Halle professor Nicolaus Hieronymus Gundling's private collegium on the history of learning. Between 1734 and 1737, Gundling's former student, Christian Friedrich Hempel, edited and published four volumes of his and other students' notes from the collegium. ${ }^{80}$ The hard and uncompromising tone of the publication created an outrage. Even Stolle declared that notes were so offensive that they could not have originated from Gundling. ${ }^{81}$ In his editorial preface, Hempel justified the publication by the honesty and frankness of the private collegia. 'In their collegia,' Hempel argued, professors reasoned 'much more freely than what is otherwise advisable in the writings that they present to the publisher. ${ }^{82}$ However, he disregarded Gundling's discretion - and the sanctity of the professorial house - and argued that:

Those who still find these Collegia Gundlingiana odious should, in any case, put them aside and just hand them over to the usage of others who understand how to make use of them. Experience teaches us manifold, how those who heard the living words of the deceased teacher found constant pleasure in what now is being published. Why shouldn't at least others of their kind receive the same satisfaction through such printed collegia $?^{83}$

Gundling based his collegium upon Heumann's Conspectus reipublicae litterariae. Like Heumann, he stressed the irrelevance of the personal life and outer appearances of scholars and philosophers.

\footnotetext{
${ }^{78} \mathrm{G}$. Stolle, Anleitung zur Historie der Gelahrheit denen zum besten so den Freyen Künsten und der Philosophie obliegen, in dreyen Theilen nunmehr zum drittenmal, verbessert und mit neuen Zusätzen vermehret, herausgegeben (Jena, 1727), 3: 'nicht blos lesen, sondern auch gelehrter Männer Collegia frequentiren, und ihren Umgang suchen'.

${ }^{79}$ Stolle, 3: 'Man schreibt nicht alles was man weiß. Ein Lehrer sagt manches in Collegio, was er nicht drucken läst. Und in der Conversation, wo nur einer oder ein paar zugegen sind, geht es insgemein noch offenhertziger heraus, als im Collegio, da ihn die Vielheit der Auditorium noch in etwa zurücke hält.'

${ }^{80}$ N. H. Gundling, Vollständige Historie der Gelahrheit, Oder Ausführliche DISCOURSE, So er in verschiedenen Collegiis Literariis, so wohl über seine eigenen Positionen, als auch vornehmlich über Tit. Herrn Inspectoris D. CHRISTOPHORI AVGVSTI HEVMANNI Conspectum Reipublicae Literariae gehalten, Mit nöthigen Anmerckungen erläutert, ergäntzet, und bis auf ietzige Zeiten fortgesetzet, Samt einer ausführlichen Beschreibung des Lebens, aller und ieder Schrifften, Collegiorum, besonderer Meinungen und gehabter Controversien des seel. Geh. Rath Gundlings, Mit doppelten nützlichen Registern, so wohl derer Auctorum, als auch derer merckwürdigen sachen, und einer Vorrede Herrn Johann Erhard Kappens, 5 vols (Frankfurt am Main, 1734-6).

${ }^{81} \mathrm{G}$. Stolle, Anmerckungen über D. Heumanns CONSPECTVM REIPVBLICAE LITERARIAE, allen Liebhabern der Historie der Gelahrheit zu Liebe an den Tag gegeben (Jena, 1738), Vorrede, unpag.

${ }^{82}$ Gundling, Historie der Gelahrheit, 1734-6, vol. 1, Vorrede des Editoris, unpag: 'in ihren Collegis, viel freyer, als es sonst rathsam ist, in denenjenigen Schriften, die sie der Presse untergeben'.

${ }^{83}$ Gundling, vol. 3, Vorrede, unpag: 'Wem also dergleichen Collegia Gundlingiana odieux bleiben, der lege sie, allenfals, bey Seite und lasse sie doch nur Andern, die selbige gar wohl zunutzen wissen, zu ihrem Gebrauch, in Händen; indem die Erfahrung vielfälting gelehrt; Wie Diejenigen beständig darmit vergnügt seyn, so, von dem seligen Docente, Ebendas, Was Jetzo, nach seinem Tode, abgedruckt wird, vica voce, gehört haben. Wie sollten denn nun nicht wenigstens Andere ihres Gleichen, durch solche abgedruckte Collegia, gleiche Satisfaction bekommen.'
} 
There was no reason to care "who dressed in blue trousers and green socks'. ${ }^{84}$ The core of the history of learning was the development of ideas and opinions. If one focused upon personal details, he admonished, one would only have 'a corpse without a soul' ${ }^{85}$ In the Republic of Letters of the past, as in the Republic of Letters of Gundling's collegium, only arguments mattered. One should, to rephrase Heumann, see the philosopher, not his robe or his books. However, only the intimacy of Gundling's household enabled such detachment, as the commotion around Hempel's publication proved.

Another student, Johannes Michael von Loen, remembered the lively and open atmosphere within Gundling's house. The professor was a merciless critic and he especially ridiculed his superior, chancellor Ludewig, whom he claimed lived 'in the land of fairies and dreams, ${ }^{86}$ Like Thomasius, Gundling engaged with his students and Loen recalled that: 'During his lectures, one often laughs more than at a comedy. He also himself laughs so heartily that his round belly shivers' ${ }^{87}$ Loen also emphasized the intimacy of the household - and the proximity of teaching and living quarters through a risque rumour about Gundling's wife. Possibly, the rumour was just the expression of adolescent fantasy, but it - no less than Hempel's publication - reflected the students' difficulties with the theory of functionalist personae. The distinctions between formality and informality, inside and outside, clothing and non-clothing, visibility and invisibility were not as clear in everyday praxis as in theory. The rumour, as Loen recounted it, even indicated that these professorial distinctions were somewhat fictitious:

The wife [...] looks great: she has all the lures of a voluptuous Venus priestess. One tells that once a young nobleman, who attended [Gundling's] collegia, took the wrong door and entered into the wife's room. One does not know what then made the good professor betake himself from his lecture hall to this same [room]. Learned people have all kinds of vagaries. Anyhow, he came into her parlour and found next to her a beautiful blonde wig hanging on a chair. He asked her who had brought it there. The impish woman, as rich in whims as in infidelities, answered: She had long wanted to see him with a good wig on his head and, thus, had ordered one in secret, hoping that it would please him. The wise man believed his polite wife, or at least pretended to. He put the wig on and left. The nobleman, who had been in hiding during this conversation, emerged again and had to endure putting on the professor's small dirty wig, and left the house with it. ${ }^{88}$

\section{THE AFTERLIFE OF THOMASIUS'S EDUCATIONAL PROGRAMME}

During the 1720s and 1730s, Thomasius's eclectic school lost ground to Christian Wolff's rationalistic school. ${ }^{89}$ According to Wolff, the philosopher was not just a function within a broader civil order, but the embodiment of divine reason. God was the highest philosopher and the human philosopher

\footnotetext{
${ }^{84}$ Gundling, vol. 1, 21: 'welche blaue Hosen und grüne Strüpffe getragen haben'.

${ }^{85}$ Gundling, vol. 1, 17: 'nur ein Cadaver; Anima deficit'.

${ }^{86}$ J. M. von Loen, Gesammelte kleine Schriften, edited by J. C. Schneidern, 2 vols (Frankfurt am Main, 1753), vol. 1, 219: 'in dem Land der Feen und der Träume'.

${ }^{87}$ von Loen, vol. 1, 219: 'In seinen Lesstuden lacht man öfters mehr, als in einer Comödie. Er lacht auch selbst hertzlich mit, daß ihm darüber sein dicker Bauch schockelt.'

${ }^{88}$ von Loen, vol. 1, 220-1: 'Die Frau geheime Räthin siehet wohl aus: sie hat alle Reitzungen einer wollüstigen Venuspriesterin. Man erzehlet, daß einsmals ein junger Edelmann, der bey ihm die Collegia besuchte, der rechten Thüre verfehlet, und zu der Frauen ins Zimmer gekommen wäre. Man weis nicht, was den guten Professor eben damals nöthigte, aus seinem Hörsal sich zu derselbigen zu begeben. Gelehrte Leute haben allerhand Einfälle. Genug, er kam in ihre Stube, und fand bey ihr eine schöne blonde Perucke auf einem Stuhl hangen. Er fragte, wer solche dahin gebracht hätte? Das verschmitzte Weib, so reich an Einfällen, als an Buhlerstreichen, antwortete: Sie hätte ihm längst gern eine gute Parucke auf dem Kopf gesehen, und zu dem Ende diese heimlich bestellen lassen, in Hofnung, sie würde ihm gefallen. Der weise Mann glaubte seiner höflichen Frauen oder that zu wenigsten so: Er setzte die Parucke auf, und gieng davon. Der Edelmann, der sich lang versteckt hatte, als diese Unterredung währete, kam darauf wieder zum Vorschein, und muste sich bequemen, des Herrn Professors kleine schmutzige Perucke aufzusetzen, und damit sich aus dem Hause zu machen.'

${ }^{89}$ Christian Wolff: Seine Schule und seine Gegner, edited by H.-M. Gerlach (Hamburg: Meiner, 2001).
} 
was God's messenger to mankind ${ }^{90}$ Thus, the philosopher should not hide behind his social and historical masks, but instead conquer the scene and speak with the clear voice of universal truth. '[A] philosopher,' Wolff declared in 1713, 'creates with his understanding so sweet a pleasure that nothing else in this world can offer us a similar [pleasure]. ${ }^{91}$

For Heumann, the place of the philosopher within history remained a problem. Throughout the many editions of his Conspectus reipublicae litterariae, he again and again rewrote his chapter on the universal category of the scholar. He attempted to save the heroes of eclectic philosophy - Thales, Socrates, Petrarch, Lefévre d'Étaples, Erasmus, Luther and Thomasius - from the anonymity of the past and admitted that others - Aristotle and Descartes - unrightfully had changed the course of events. In his Acta philosophorum, he discussed how customs, nationality, religion, upbringing and education shaped the minds and thoughts of philosophers..$^{92}$ Even if the personal lives of philosophers were irrelevant to the history of philosophy, history was not irrelevant to these philosophers. For Wolff and his followers, such temporal considerations were now obsolete. The philosopher had overcome history. In 1763, one critical observer emulated the conformity and overconfidence of Wolffian textbooks:

Everything was dark in ancient philosophy, even the concept of the philosopher, and this darkness continued until our times. For in the Middle Ages people knew no other philosophers than Aristotelians, wizards, and gold-makers. Descartes first taught us to define, and Wolff to demonstrate. The mathematical method arrived and everything became illuminated in philosophy. If you now ask what a philosopher is, then we only find one and the same definition in all of our textbooks and in this [definition] nothing is undeclared or undefined. ${ }^{93}$

Despite the triumph of Wolff's school, and its dominance upon the textbook market, Thomasius's eclectic and civil philosophy continued to have followers. It remained powerful within law faculties and, through these, influenced German philosophy throughout the eighteenth century. ${ }^{94}$ Thomasius's educational programme also helped shape the future of German universities. The Thomasius school undermined the early modern unified systems of knowledge. ${ }^{95}$ Christian Wolff reinstated a unified system, but eclectic academics continued the compartmentalization of German scholarship. Under the thin garments of Wolffian metaphysics, this process of specialization continued throughout the eighteenth century and, ultimately, culminated with the formation of disciplines during the early nineteenth century. ${ }^{96}$

The eclecticism of disciplines was not the individualized eclecticism of Thomasius. The dialogue no longer happened within the philosopher, but between heterogeneous communities of academics. Around the turn of the nineteenth century, the private collegia in the professorial house changed

\footnotetext{
${ }^{90} \mathrm{C}$. Wolff, Vernünfftige Gedancken von Gott, der Welt und der Seele des Menschen, auch allen Dingen überhaupt (Frankfurt am Main, 1736), 602. See W. Schmidt-Biggemann, Theodizee und Tatsachen. Das philosophische Profil der deutschen Aufklärung (Frankfurt am Main: Suhrkamp, 1988), 14-5.

${ }^{91} \mathrm{C}$. Wolff, Vernünfftige Gedancken von den Kräften des menschlichen Verstandes und ihrem richtigen Gebrauche in Erkenntni $\beta$ der Wahrheit (Halle, 1713), 116: 'ein Welt-Weiser [...] schöpffet aus seiner Erkäntniß ein so süsses Vergnügen, dergleichen uns nicht anders in der Welt gewehren kann'.

${ }^{92}$ Heumann, Acta philosophorum, 1715-23, esp. vol. 4, 567-670.

${ }^{93}$ J. S. Sneedorff, Samtlige Skrivter, 9 vols (Copenhagen, 1775-7), vol. 5, 32-3: 'Saa mørkt var Alt i den gamle Philosophie, indtil Begrebet selv af en Philosoph, og dette Mørke varede indtil vore Tider; Thi i den midlere Alder kiendte man ikke andre Philosopher end Aristoteliker, Hexemestre og Guldmagere. Descartes lærte os først at definere, og Wolf at demonstrere. Den Mathematiske Methode kom op, og Alting blev lyst i Philosophien. Spørger man nu, hvad en Philosoph er? da finde vi kuns een og den samme Definition i alle vore Lære-Bøger, og i denne er intet uforklaret eller ubestemt.'

${ }^{94}$ N. Hammerstein, Jus und Historie: Ein Beitrag zur Geschichte des historischen Denkens an deutschen Universitäten im späten 17. und im 18. Jahrhundert (Göttingen: Vandenhoeck und Ruprecht, 1972), T. J. Hochstrasser, Natural Law Theories in the Early Enlightenment (Cambridge: Cambridge University Press, 2000), and I. Hunter, Rival Enlightenments: Civil and Metaphysical Philosophy in Early Modern Germany (Cambridge: Cambridge University Press, 2001).

${ }^{95} \mathrm{~W}$. Schmidt-Biggemann, Topica universalis. Eine Modellgeschichte humanistischer und barocker Wissenschaft (Hamburg: Meiner, 1983), 249-92. Dreitzel, 'Zur Entwicklung und Eigenart', 1991, esp. 337-43.

${ }_{96}^{6}$. Stichweh, Zur Entstehung des modernen Systems wissenschaftlicher Disziplinen. Physik in Deutschland 1740-1890 (Frankfurt am Main: Suhrkamp, 1984).
} 
accordingly. The German pioneers of disciplinarity had no interest in emancipating their students. On the contrary, their private exercises trained students to think and write alike and, thus, produced coherence and uniformity within the disciplines. ${ }^{97}$ Students still learned to forget their personal backgrounds, religious sentiments, and political affiliations, but, during the early nineteenth century, this process of detachment became its own purpose. One no longer entered the professorial home to become an independent and critical philosopher, but - as Immanuel Kant foresaw - an anonymous 'worker on the building of scholarship'. 98

Roskilde University

\footnotetext{
${ }^{97}$ K. R. Eskildsen, 'Leopold von Ranke, la passion de la critique et le séminaire d'historie', Lieux de savoir: Espaces et communautés, edited by C. Jacob (Paris: Albin Michel, 2007), 462-482. Also T. Lenoir, 'The Discipline of Nature and the Nature of Disciplines', and K. W. Hoskin 'Education and the Genesis of Disciplinarity', in Knowledges: Historical and Critical Studies of Disciplinarity, edited by E. Messer-Davidow, D. R. Shumway, and D. J. Sylvan (Charlottesville: University Press of Virginia, 1993), 70-102 and 271-304.

${ }_{98}$ Immanuel Kant, Gesammelte Schriften, 29 vols (Berlin: Königlich Preußischen Akademie der Wissenschaften, 1900-), vol. 7 , 280, note: 'Arbeiter am Gebäude der Wissenschaft'.
} 